\title{
Optimization of Ethanol Production from Cheese Whey Fermentation in a Batch-Airlift Bioreactor
}

\author{
H. Ghanadzadeh* and M. Ghorbanpour \\ Department of Chemical Engineering, University of Guilan, Rasht, Iran
}

\begin{abstract}
In this work, Kluyveromyces fragilis yeast was used for bio-ethanol production from cheese-whey in batch fermentation. The present study consisted of two steps: The first was a central composite design (CCD) for evaluating of important factors including: $\mathrm{pH}$, initial lactose concentration $(\mathrm{L})$, yeast cells concentrations $(\mathrm{Y})$ and temperature (T). In order to optimize the fermentation process, response surface methodology (RSM) was used in this stage. The best operating conditions were found to be $\mathrm{pH}=5.3, \mathrm{~L}=41.8 \mathrm{~g} / \mathrm{l}, \mathrm{Y}=0.57 \mathrm{~g} / \mathrm{l}$ and $\mathrm{T}=30.8^{\circ} \mathrm{C}$. The second step was to determine the effect of aeration rate on the fermentation process in an airlift bioreactor. The best conditions were the aeration rate of $0.4 \mathrm{vvm}$ with $89.28 \%$ of ethanol production yield. In this research, the concentrated cheese whey was also used for obtaining a bio-ethanol fermentation product.
\end{abstract}

Keywords: Fermentation; Bio-ethanol; Cheese whey; Response surface methodology; Airlift bioreactor

\section{Introduction}

Cheese whey is a yellowish liquid remaining after milk coagulates during cheese production. It is a by-product of the manufacture of cheese and has several commercial uses. Cheese whey is produced in huge amounts and is a significant environmental problem due to the high levels of organic matter content [1]. Cheese whey represents a biochemical oxygen demand (BOD) of 30-50 g/l and a chemical oxygen demand (COD) of 60-80 g/l lactose is largely responsible for the high $\mathrm{BOD}$ and COD, since protein recovery reduces only about $12 \%$ of the whey COD [2-4]. On the other hand, whey retains much of the milk nutrients, including functional proteins and peptides, lipids, lactose, minerals and vitamins and therefore has a vast potential as a source of added value compounds, challenging the industry to face whey surplus as a resource [5,6]. In Iran, about 1.8 million tons of whey which is the by-product of cheese producing factories is produced each year. The changing of whey into alcohol due to the low price of whey (compare to the price of other raw materials) has become the focus of considerable attention in the world. Use of whey in the preparation of ethanol was studied since 1940. Moulin et al. [7] have achieved to the 86 to 90 percent of efficiency in the medium of cheese whey permeate by using the two species of yeasts Kluyveromyces fragilis and Candida pseudotropicalis. In a study by Gawel et al. [8] with K.fragilis strain obtained to 10 percent of ethanol fermentation from whey in 15 days. Janssens et al. [9] reported ethanol productivity of $7.1 \mathrm{gL}^{-1} \mathrm{~h}^{-1}$ for $K$. fragilis operating with cell recycling at $\mathrm{D}=0.15 \mathrm{~h}^{-1}$ and for cheese whey permeate (CCWP) with $100 \mathrm{~g} / \mathrm{l}$ lactose. Terrell et al. [10] reported ethanol productivity of $13.6 \mathrm{gL}^{-1} \mathrm{~h}^{-1}$ for CCWP with $150 \mathrm{~g} / \mathrm{l}$ lactose concentration operating at continuous operation. Ryu et al. [11] reached to the rate of 2.1 percent of ethanol in a batch system in airlift bioreactor by using K.fragilis (20 L). Ferrarie et al. [12] were obtained $64 \mathrm{~g} / \mathrm{l}$ of ethanol in a fed-batch system. In this research the laboratory production of ethanol by means of whey has been accomplished in an airlift bioreactor. The purposes of the present experimental study were mainly to investigate how the main operating parameters affect the process so as to determine which of them were certainly important. The goals were satisfied by means of response surface methodology through accurately designed central composite design.

\section{Culture Media and Batch Cultures}

\section{Microorganism}

Yeast strain used in this study was K. fragilis PTCC 5193, obtained from the Iranian Research Organization for Science and Technology (IROST). K. fragilis was maintained in agar $(65 \mathrm{~g} / \mathrm{l})$. The culture was sterilized in autoclave at $121^{\circ} \mathrm{C}$ for $20 \mathrm{~min}$; the yeast inoculum was spread on the surface and incubated at $30^{\circ} \mathrm{C}$ for $48 \mathrm{hrs}$. At completed growth, the slants were preserved at $4^{\circ} \mathrm{C}$.

\section{Preculture medium}

The preculture medium was $13 \mathrm{~g} / \mathrm{l}$ nutrient broth, $10 \mathrm{~g} / \mathrm{l}$ peptone and $10 \mathrm{~g} / \mathrm{l}$ yeast extract, sterilized at $121^{\circ} \mathrm{C}$ for $15 \mathrm{~min}$ and prepared with a single colony withdrawn from the slants and maintained for 48 hrs at an incubator shaker with a temperature of $35^{\circ} \mathrm{C}$ and velocity of $150 \mathrm{rpm}$. In all the experiments $100 \mathrm{ml}$ of sterile Erlenmeyer flask were charged with a $50 \mathrm{ml}$ of preculture.

\section{Fermentation medium}

Cheese whey was the fermentation medium; containing lactose $(4.5-5 \% \mathrm{w} / \mathrm{v})$, soluble proteins $(0.6-0.8 \% \mathrm{w} / \mathrm{v})$, lipids $(0.4-0.5 \% \mathrm{w} / \mathrm{v})$ and mineral salts $(8-10 \%$ of dried extract). Whey also contains appreciable quantities of other components, such as lactic $(0.05 \% \mathrm{w} / \mathrm{v})$ and citric acids, non-protein nitrogen compounds (urea and uric acid) and $\mathrm{B}$ group vitamins $[3,4]$. For batch experiments five hundred milliliters of erlenmeyer flasks were charged with $300 \mathrm{ml}$ of cheese sterilized and deprotenized whey. It consisted of yeast extract $(5 \mathrm{~g} / \mathrm{l})$, peptone $(5 \mathrm{~g} / \mathrm{l})$, $\mathrm{NH}_{4} \mathrm{Cl}(2 \mathrm{~g} / \mathrm{l}), \mathrm{KH}_{2} \mathrm{PO}_{4}(1 \mathrm{~g} / \mathrm{l}), \mathrm{MgSO}_{4} .7 \mathrm{H}_{2} \mathrm{O}(0.3 \mathrm{~g} / \mathrm{l})[13,14]$. Variables were $\mathrm{pH}$, initial lactose concentration $(\mathrm{L})$, yeast cells concentrations $(\mathrm{Y})$ and temperature $(\mathrm{T})$.

*Corresponding author: H. Ghanadzadeh Gilani, Department of Chemical Engineering, University of Guilan, Rasht, Iran, Tel: +98-0131-6690597; E-mail: hggilani@guilan.ac.ir

Received October 28, 2011; Accepted January 27, 2012; Published January 29 2012

Citation: Ghanadzadeh H, Ghorbanpour M (2012) Optimization of Ethanol Production from Cheese Whey Fermentation in a Batch-Airlift Bioreactor. J Bioengineer \& Biomedical Sci 2:111. doi:10.4172/2155-9538.1000111

Copyright: (c) 2012 Ghanadzadeh H, et al. This is an open-access article distributed under the terms of the Creative Commons Attribution License, which permits unrestricted use, distribution, and reproduction in any medium, provided the original author and source are credited. 


\section{Airlift bioreactor}

Figure 1 shows an airlift bioreactor contains external loop which is made of Pyrex glass. The bioreactor was fed with sweet cheese sterilized and deprotenized whey. The cell suspension was aseptically transferred to the bioreactor. Airlift bioreactor was operated at working volume of 7 liters that included $10 \%$ preculture. The regulation system allows for: temperature control at $30 \pm 1^{\circ} \mathrm{C}$; foam-level and $\mathrm{pH}$ controlled by addition of antifoam and ammonia, respectively. The set-point fixed at pH $5.0 \pm 0.1$. The system was aerated with filtered air at a different flow rate of $0.1,0.4$ and $0.8 \mathrm{vvm}$ that was controlled using an aeration pump controller. Each run was achieved in duplicates; the average values of lactose, ethanol and biomass concentrations were calculated and monitored with respect to time.

\section{Analytical methods}

In the Erlenmeyer flask after $48 \mathrm{hrs}$ all of the samples were removed and centrifuged and in airlift bioreactor the samples were removed from the sampling ports at different heights of the column every day and centrifuged at $8000 \mathrm{rpm}$ for $20 \mathrm{~min}$ to remove solids from the liquid media. Total reducing sugar concentrations were measured by using the phenol-acid method [2]. The samples were analyzed in triplicates 3\%. Ethanol concentrations were measured using a Varian CP-3800 gas chromatograph (GC) equipped with a thermal conductivity detector (TCD) and star integrator. A $2 \mathrm{~m} \times 1.4$ " $\times 4 \mathrm{~mm}$ column packed with propack Q 89-100 Mesh. The column temperature was set for $75^{\circ} \mathrm{C}$ for $1 \mathrm{~min}$ and raised to $150^{\circ} \mathrm{C}$ with a rate of $10^{\circ} \mathrm{C} / \mathrm{min}$ yielding a total hold time of $4.75 \mathrm{~min}$. Temperatures of injector and detector were 150 and $200^{\circ} \mathrm{C}$, respectively. Nitrogen was used as the carrier gas

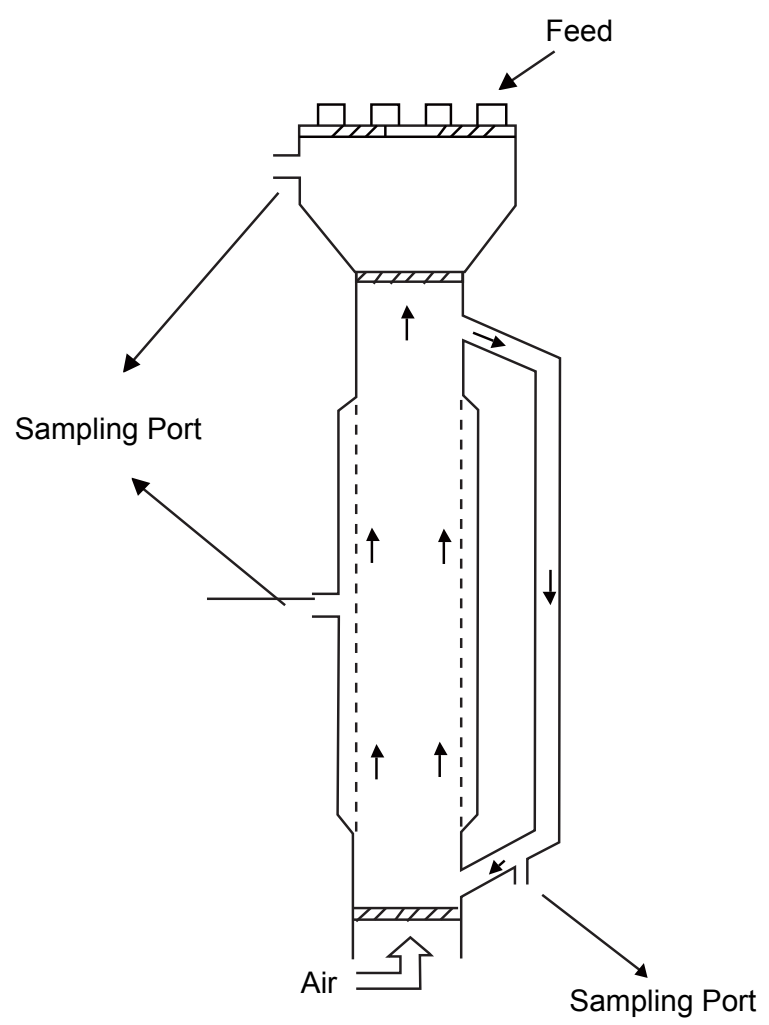

Figure 1: Schematic of the airlift bioreactor with a linear velocity of $30 \mathrm{ml} / \mathrm{min}$. Dry cell mass concentration was estimated by measuring the optical density of the sample at $600 \mathrm{~nm}$ in a spectrophotometer, and by its correlation with the dry cell weight (DCW) obtained gravimetrically. $\mathrm{pH}$ was measured using a $\mathrm{pH}$ meter (JEYWAY 3510). The yeast cells concentration was estimated by the dry weight method. The dry weight cell concentration was determined by filtering the sample through $0.2 \mu \mathrm{m}$ filter paper and then dried at $105^{\circ} \mathrm{C}$ for $48 \mathrm{hrs}$ [15].

\section{Experimental design}

The present experimental study consisted of two steps: (1) The central composite design (CCD) aimed at determining the effects of 4 factors on the fermentation process.

(2) Determining the effect of aeration rate on the fermentation process and measuring the variation of ethanol, lactose and biomass concentration with time in airlift bioreactor.

Four factors were considered to perform for response surface methodology of CCD: $\mathrm{pH}$, initial lactose concentration (L), yeast cells concentration $(\mathrm{Y})$ and temperature $(\mathrm{T})$, with five different levels for each of the factors. The values of the chosen factors were 4 and 6 for $\mathrm{pH}$, 40 and 80 for initial lactose concentration, 0.4 and $0.8 \mathrm{~g} / \mathrm{l}$ for yeast cells concentration and 30 and 38 for temperature. The range of these values was considered since it characterized the optimum range for the yeast activity and the expected range in which the process could be operated. In this study, the experimental design consisted of 25 runs and the independent variables were studied at five different levels. Table 1 shows the experimental design used for this study. All the experiments were done in duplicates and the average of ethanol production obtained was taken as the response function (RF). The Second degree polynomials, Equation (1), which contains all interaction terms, were used to calculate the predicted response:

$$
\mathrm{RF}=\beta_{0}+\sum \beta_{\mathrm{i}} \mathrm{x}_{\mathrm{i}}+\sum \beta_{\mathrm{ii}} \mathrm{x}_{\mathrm{i}}^{2}+\sum \beta_{\mathrm{ij}} \mathrm{x}_{\mathrm{i}} \mathrm{x}_{\mathrm{j}}
$$

Where RF represents response variable, $\beta_{0}$ is the interruption coefficient, $\beta_{\mathrm{i}}$ the coefficient of the linear effect, $\beta_{\mathrm{ii}}$ the coefficient of quadratic effect and $\beta_{i j}$ the $i j^{\text {th }}$ coefficient of interaction effect, xi xj are input variables which influence the response variable RF; $\beta_{\mathrm{i}}$ is the $i^{\text {th }}$ linear coefficient. Numerical analysis of the model was performed to evaluate the analysis of variance (ANOVA). For each variable, the quadratic models were represented as contour plots (3D) and response surface curves were generated.

\section{Results and Discussion}

Table 1 are shown the experimental design and results of CCD of response surface methodology. The factors levels are 4 and 6 for $\mathrm{pH}$, 40 and $80 \mathrm{~g} / \mathrm{l}$ for $\mathrm{L}, 0.4$ and $0.8 \mathrm{~g} / \mathrm{l}$ for $\mathrm{Y}$ and 30 and $38^{\circ} \mathrm{C}$ for T. In the last column the obtained response function values are shown. The experimental data were statistically analyzed using the Fischer's statistical test for analysis of variance (ANOVA) and the results are shown in Table 2. The ANOVA of the quadratic regression model indicated that the model was highly significant, as the F-value for the model was 11.52. This fit of the model was checked by the coefficient of determination $\mathrm{R}^{2}$, which was calculated to be 0.92 , indicating that $92.05 \%$ of the variability in the response could be explained by the model. The effects of the parameters on the response function (RF) were calculated and the parameters which showed P-values less than 0.05 were taken into account in the model; the other parameters were actually undistinguishable from noise. The significant terms, as shown in Table 2 , are $\mathrm{pH}, \mathrm{L}, \mathrm{T}, \mathrm{pH}^{2}$ and $\mathrm{T}^{2}$. Then, by eliminating the other 
Citation: Ghanadzadeh H, Ghorbanpour M (2012) Optimization of Ethanol Production from Cheese Whey Fermentation in a Batch-Airlift Bioreactor. J Bioengineer \& Biomedical Sci 2:111. doi:10.4172/2155-9538.1000111

Page 3 of 6

\begin{tabular}{|c|c|c|c|c|c|}
\hline Run & $\mathbf{p H}$ & $\begin{array}{c}\text { Lactose } \\
\mathbf{( g / l )}\end{array}$ & $\begin{array}{c}\text { Yeast cells con- } \\
\text { centration } \mathbf{( Y )}(\mathbf{g} / \mathbf{l})\end{array}$ & $\begin{array}{c}\text { Tempera- } \\
\left.\text { ture } \mathbf{(}^{\circ} \mathbf{C}\right)\end{array}$ & $\begin{array}{c}\text { Response Func- } \\
\text { tion (RF) }\end{array}$ \\
\hline 1 & 5 & 100 & 0.6 & 34 & 1.35 \\
\hline 2 & 5 & 20 & 0.6 & 34 & 1.55 \\
\hline 3 & 4 & 60 & 0.6 & 26 & 1.47 \\
\hline 4 & 4 & 40 & 0.4 & 30 & 1.36 \\
\hline 5 & 5 & 80 & 0.4 & 30 & 1.05 \\
\hline 6 & 6 & 60 & 0.6 & 42 & 0.85 \\
\hline 7 & 6 & 40 & 0.8 & 38 & 1.17 \\
\hline 8 & 3 & 80 & 0.8 & 38 & 1.11 \\
\hline 9 & 7 & 60 & 0.6 & 34 & 0.90 \\
\hline 10 & 4 & 60 & 0.6 & 34 & 0.98 \\
\hline 11 & 4 & 40 & 0.4 & 38 & 1.05 \\
\hline 12 & 6 & 80 & 0.4 & 38 & 0.75 \\
\hline 13 & 6 & 40 & 0.8 & 30 & 1.48 \\
\hline 14 & 5 & 80 & 0.8 & 30 & 1.42 \\
\hline 15 & 5 & 60 & 0.2 & 34 & 0.75 \\
\hline 16 & 6 & 60 & 1.0 & 34 & 0.85 \\
\hline 17 & 6 & 40 & 0.4 & 30 & 1.50 \\
\hline 18 & 6 & 40 & 0.4 & 38 & 1.20 \\
\hline 19 & 6 & 80 & 0.4 & 30 & 1.45 \\
\hline 20 & 4 & 80 & 0.4 & 38 & 1.05 \\
\hline 21 & 4 & 40 & 0.8 & 30 & 1.08 \\
\hline 22 & 4 & 40 & 0.8 & 38 & 0.75 \\
\hline 23 & 4 & 80 & 0.8 & 30 & 1.03 \\
\hline 24 & 5 & 80 & 0.8 & 38 & 0.73 \\
\hline 25 & 5 & 60 & 0.6 & 34 & 1.59 \\
\hline & 5 & & & & 30 \\
\hline
\end{tabular}

Table 1: Experimental design and CCD results of response surface methodology.

\begin{tabular}{|l|l|l|l|}
\hline \multicolumn{1}{|c|}{ Model term } & \multicolumn{1}{c|}{ Coefficient } & \multicolumn{1}{c|}{ F-value } & \multicolumn{1}{c|}{ p-value } \\
\hline Constant & -0.85776 & & \\
\hline $\mathrm{PH}$ & 1.52437 & 10.67 & 0.008 \\
\hline $\mathrm{L}$ & -0.00453 & 0.06 & 0.818 \\
\hline $\mathrm{Y}$ & 3.38646 & 3.88 & 0.077 \\
\hline $\mathrm{T}$ & 0.37703 & 5.36 & 0.043 \\
\hline $\mathrm{PH}^{2}$ & -0.15354 & 17.77 & 0.002 \\
\hline $\mathrm{L}^{2}$ & -0.00006 & 0.42 & 0.533 \\
\hline $\mathrm{Y}^{2}$ & -4.65104 & 26.09 & 0.000 \\
\hline $\mathrm{T}^{2}$ & -0.00600 & 6.95 & 0.025 \\
\hline $\mathrm{PH}-\mathrm{L}$ & 0.00119 & 0.60 & 0.456 \\
\hline $\mathrm{PH}-\mathrm{T}$ & -0.00156 & 0.04 & 0.842 \\
\hline $\mathrm{PH}-\mathrm{Y}$ & 0.18125 & 1.40 & 0.262 \\
\hline $\mathrm{L}-\mathrm{T}$ & -0.00008 & 0.04 & 0.842 \\
\hline $\mathrm{L}-\mathrm{Y}$ & 0.00906 & 1.40 & 0.264 \\
\hline $\mathrm{Y}-\mathrm{T}$ & 0.00781 & 0.04 & 0.842 \\
\hline
\end{tabular}

$R^{2}=92.05 \%$ and adjusted $R^{2}=80.91 \%$

Table 2: Coefficient estimates and analysis of variance (ANOVA) for the response surface quadratic model.

terms from the model (except L to support hierarchy as requested from the methodology [16]), Eq. (2) was obtained as a function of the significant factors.

$\mathrm{RF}=-0.8577+1.5243 \mathrm{PH}-0.0045 \mathrm{~L}+0.3770 \mathrm{~T}-0.1535 \mathrm{PH}^{2}-0.0060 \mathrm{~T}^{2}(2)$

Figure 2-4 show the effects of the factors on the RF. Figure 2a presenting the response surface performance as a function of both $\mathrm{pH}$ and L. a relatively weak effect of $\mathrm{L}$ and a stronger effect of $\mathrm{pH}$ can be noted. The best conditions were achieved at $\mathrm{pH} 5.3$ and $\mathrm{L} 41.8 \mathrm{~g} / \mathrm{l}$. With increasing lactose level of 40 to $60 \mathrm{~g} / \mathrm{l}$, RF decreased because of cellular osmotic pressure limiting. Figure $2 \mathrm{~b}$ shows the effect of $\mathrm{pH}$ and $\mathrm{T}$ on ethanol production while the third variable is fixed at its middle level.



Figure 2: (a) Response surface as a function of $\mathrm{pH}$ and lactose $(\mathrm{L})$.

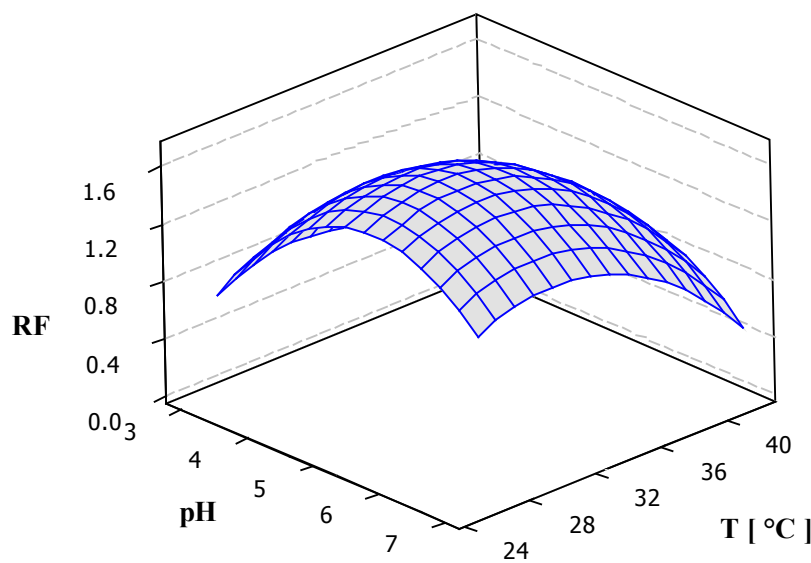

Figure 2: (b) Response surface as a function of $\mathrm{pH}$ and temperature $(\mathrm{T})$, (the other variables were fixed at middle level).

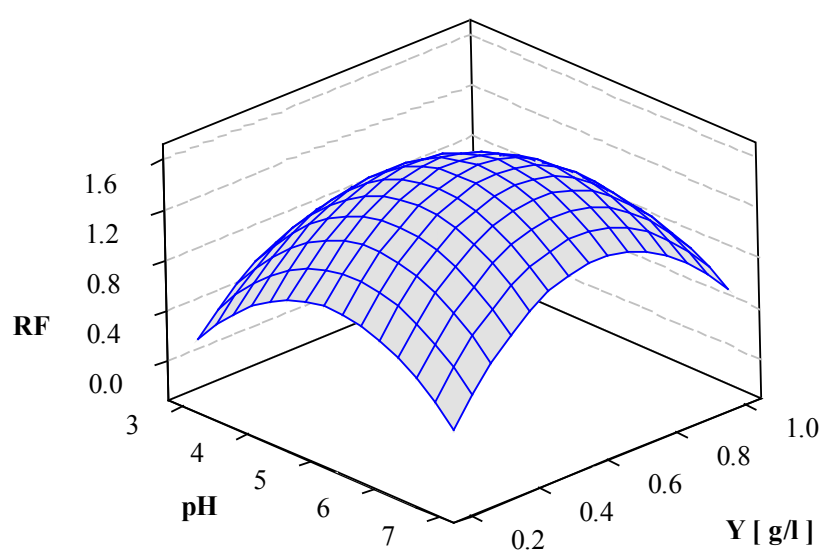

Figure 3: (a) Response surface as a function of $\mathrm{pH}$ and yeast cells concentration $(\mathrm{Y})$.

Maximum ethanol production was recorded in the middle levels of both the factors while further increase in the levels resulted in a gradual decrease in yield. It is evident that a $\mathrm{pH}$ value around 5.3 and $\mathrm{T}$ around 


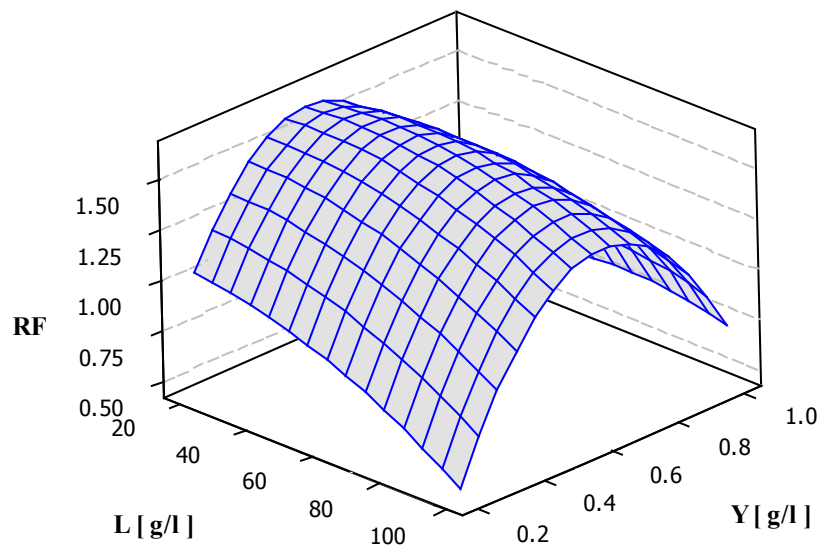

Figure 3: (b) Response surface as a function of lactose $(L)$ and yeast cells concentration $(Y)$, (the other variables were fixed at middle level).

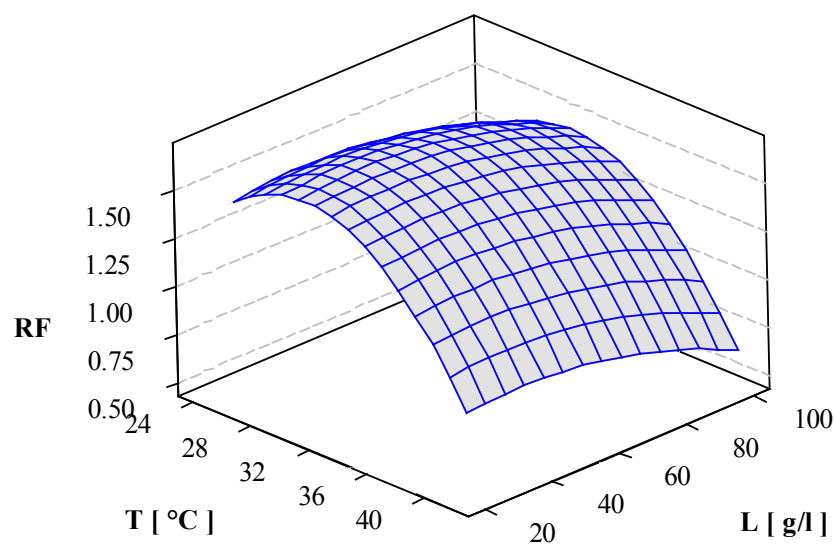

Figure 4: (a) Response surface as a function of lactose $(L)$ and temperature $(T)$

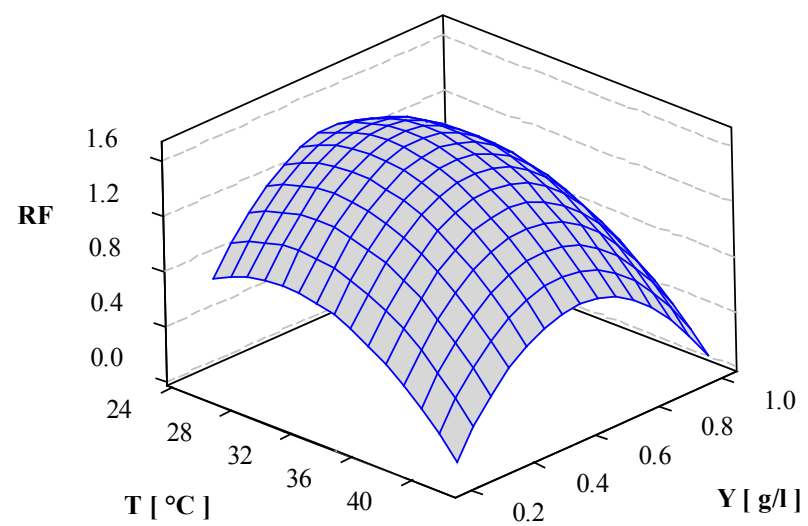

Figure 4: (b) Response surface as a function of yeast cells concentration( $\mathrm{Y}$ ) and temperature $(\mathrm{T})$, (the other variables were fixed at middle level).

$30.8^{\circ} \mathrm{C}$ improves the fermentation process. Results presented in Figure 3a shows the interaction between $\mathrm{pH}$ and $\mathrm{Y}$; the best conditions were obtained at $\mathrm{pH} 5.3$ and Y $0.57 \mathrm{~g} / \mathrm{l}$. The worst conditions were achieved at $\mathrm{pH} 3$ and at a $\mathrm{Y}$ of both 0.2 and $1 \mathrm{~g} / \mathrm{l}$. Figure $3 \mathrm{~b}$ showing the RF dependence on both $\mathrm{L}$ and $\mathrm{Y}$, confirms that it should be advisable to use intermediate $\mathrm{Y}$ values and low $\mathrm{L}$ values. Figure 4a presents the response surface versus $\mathrm{L}$ and $\mathrm{T}$; it strengthens the conviction that CW fermentation process is enhanced by relatively low $\mathrm{T}$ values. Factor $\mathrm{L}$ has a weak effect on the RF, even though better results were achieved with the lowest value of $\mathrm{L}$, about $41.8 \mathrm{~g} / \mathrm{l}$. Figure $4 \mathrm{~b}$ exhibits a strong response surface dependence on both $\mathrm{Y}$ and $\mathrm{T}$; Moreover, a good system behavior corresponding to a RF of 1.4, is obtained at $\mathrm{Y}=$ $0.57 \mathrm{~g} / \mathrm{l}$ and $\mathrm{T}=30.8^{\circ} \mathrm{C}$. The RSM showed that the best set of operating conditions as following: $\mathrm{pH}=5.3, \mathrm{~L}=41.8 \mathrm{~g} / \mathrm{l}, \mathrm{Y}=0.57 \mathrm{~g} / \mathrm{l}$ and $\mathrm{T}=$ $30.8^{\circ} \mathrm{C}$, with a predicted value of the RF of 1.69 (the optimization was strictly performed in the considered range of the factors). Figures 5 and figure 6 show the effect of aeration rate on the ethanol production and the time course of cell, lactose and ethanol concentrations, using ordinary whey media as substrate, in Erlenmeyer and airlift bioreactor cultures. Figure $5 \mathrm{a}$ Shows the maximum amount of alcohol produced in non-aerated conditions in Erlenmeyer, after 65 hours from when fermentation started, is $2.9(\mathrm{w} / \mathrm{v})$ percent. Figure $5 \mathrm{~b}$ shows that ethanol production is $2.9(\mathrm{w} / \mathrm{v})$ percent after 36 hours for aeration rate of 0.1 vvm in airlift bioreactor. Comparing these two figures shows that amount of ethanol productions are as the same clearly but the duration time of figure $5 b$ to reach the maximum amount of alcohol is shorter, because the aeration operation makes the yeast growth faster. Figure 6a shows the ordinary whey media fermentation with $0.4 \mathrm{vvm}$ aeration rate in the bioreactor. The maximum amount of alcohol production after 17 hours was obtained $3(w / v)$ percent. Figure $6 \mathrm{~b}$ shows that the

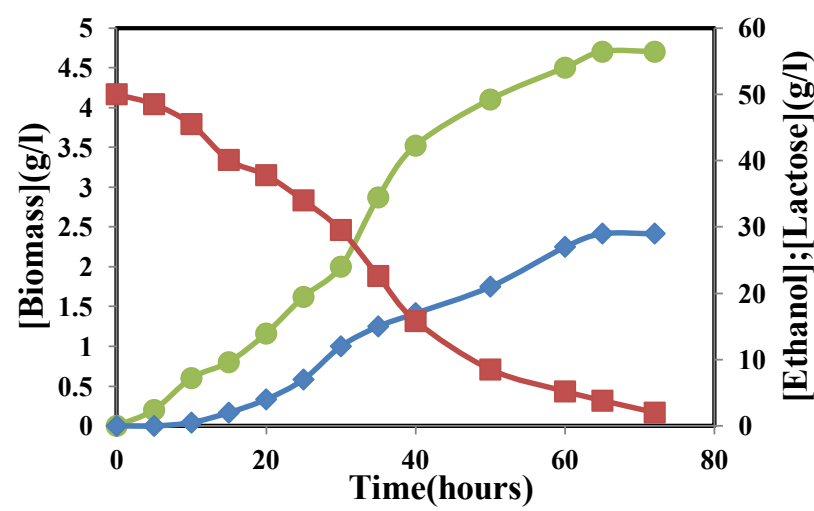

Figure 5: (a) Cell $(\bullet)$, lactose $(\bullet)$ and ethanol $(\bullet)$ concentration profiles fo ordinary whey media with $50 \mathrm{~g} / \mathrm{l}$ lactose (a) without aeration rate.

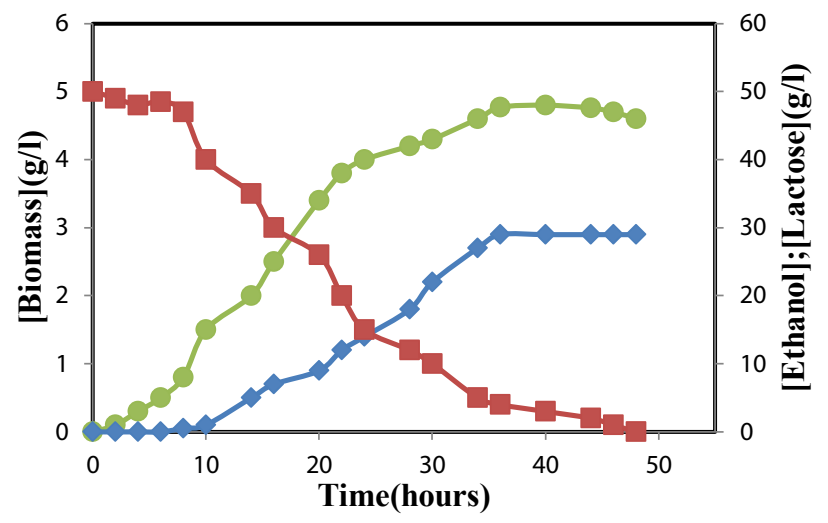

Figure 5: (b) with aeration rate of $0.1 \mathrm{vvm}$. 


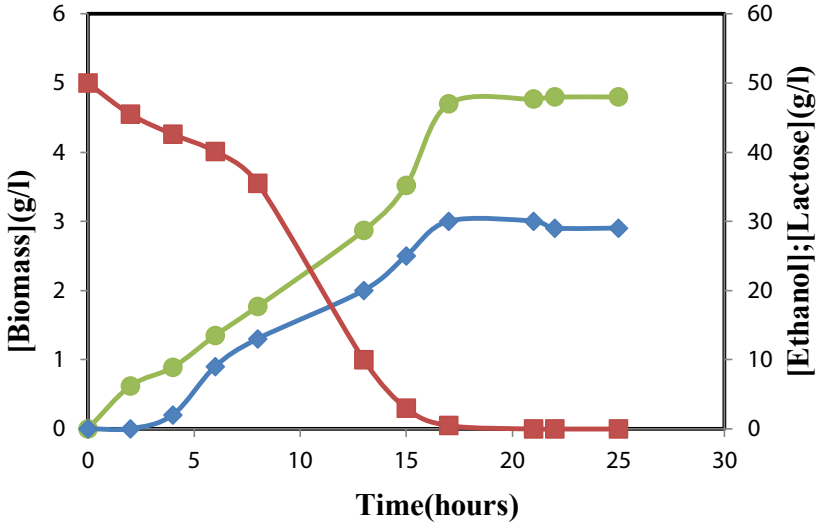

Figure 6: (a) Cell $(\bullet)$, lactose $(\bullet)$ and ethanol $(\bullet)$ concentration profiles for ordinary whey media with $50 \mathrm{~g} / \mathrm{l}$ lactose with (a) aeration rate $0.4 \mathrm{vvm}$.

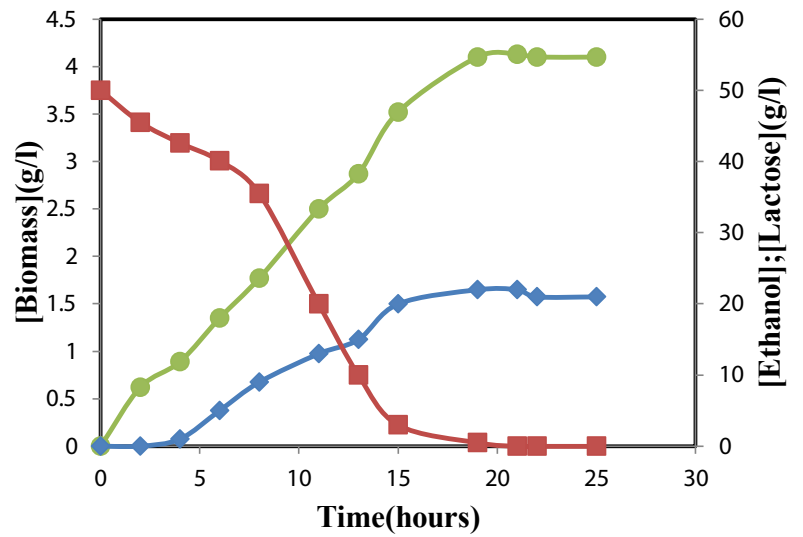

Figure 6: (b) aeration rate $0.8 \mathrm{vvm}$ in airlift bioreactor.

highest value of alcohol production is $2.2(\mathrm{w} / \mathrm{v})$ percent with $0.8 \mathrm{vvm}$ aeration rate in the nineteenth hours of the fermentation time. As can be seen with the increase of aeration rate of 0.1 to $0.4 \mathrm{vvm}$ the amount of alcohol remained approximately constant, but the duration time to reach the maximum amount of alcohol was lower and with further increase of aeration rate of 0.4 to $0.8 \mathrm{vvm}$ the alcohol production rate was decreased, because the fermentation process was anaerobic in nature but the yeast to grow needed a small amounts of oxygen and the excess of the required was reduced the rate of production. The optimum aeration rate for alcohol production is $0.4 \mathrm{vvm}$. Figure 7 illustrates that the amount of alcohol produced is $6.1(\mathrm{w} / \mathrm{v})$ percent in concentrated whey media of $100 \mathrm{~g} / \mathrm{l}$ lactose and $0.4 \mathrm{vvm}$ aeration rate. The use of yeast extract $(5 \mathrm{~g} / \mathrm{l})$, peptone $(5 \mathrm{~g} / \mathrm{l}), \mathrm{NH}_{4} \mathrm{Cl}(2 \mathrm{~g} / \mathrm{l}), \mathrm{KH}_{2} \mathrm{PO}_{4}(1 \mathrm{~g} / \mathrm{l})$, $\mathrm{MgSO}_{4} \cdot 7 \mathrm{H}_{2} \mathrm{O}(0.3 \mathrm{~g} / \mathrm{l})$ and lactose $(50 \mathrm{~g} / \mathrm{l})$ increased amount of alcohol considerably (Approximately 3 percent).

\section{Conclusions}

Central composite design and response surface methodology can be used for the purpose of finding the maximum production of ethanol by Kluyveromyces fragilis. This design based on the analysis of 25 experiments, involving the anaerobic fermentation of lactose contained in cheese whey, was performed. The effects of four factors, $\mathrm{pH}$ and initial

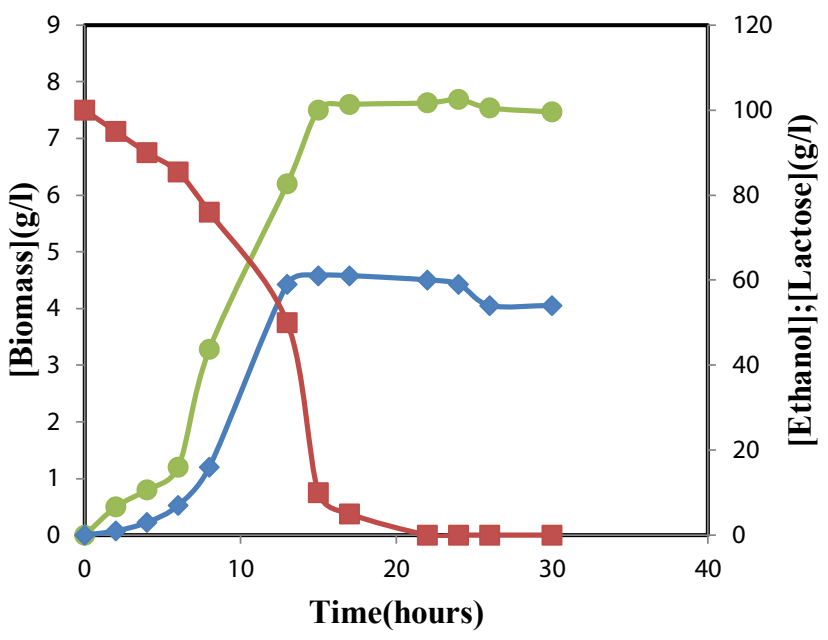

Figure 7: Cell $(\bullet)$, lactose $(\bullet)$ and ethanol $(\bullet)$ concentration profiles for concentrated whey media with aeration rate $0.4 \mathrm{vvm}$ and lactose $100 \mathrm{~g} / \mathrm{l}$.

lactose concentration $(\mathrm{L})$ yeast cells concentration $(\mathrm{Y})$ and temperature (T) were estimated. After having accomplished the ANOVA test on the complete quadratic model, all the negligible effects were removed in order to improve the model predictive performance. A response surface quadratic model was obtained as a function of the only significant effects, $\mathrm{pH}, \mathrm{L}, \mathrm{T}, \mathrm{pH}^{2}$ and $\mathrm{T}^{2}$. On the other hand, an adjusted $\mathrm{R}^{2}$ value of 0.92 , testified a good model correlation performance. The optimization showed that the best set of operating parameters to operate the fermenter was 5.3 for $\mathrm{pH}, 41.8 \mathrm{~g} / \mathrm{l}$ for initial lactose concentration, 0.57 $\mathrm{g} / \mathrm{l}$ for yeast cells concentration and $30.8^{\circ} \mathrm{C}$ for temperature. Also in this research the laboratory production of ethanol by means of whey has been accomplished in an airlift bioreactor. The major aim of this stage is determining the effect of aeration rate on the fermentation process in the airlift bioreactor (7L) and measuring the variation of ethanol, lactose and cell (biomass) concentration with time. Experiments at this stage in four cases, the fermentation in normal whey media with $50 \mathrm{~g} / \mathrm{l}$ lactose without aeration rate in the Erlenmeyer flask and with aeration rate of $0.1,0.4$ and $0.8 \mathrm{vvm}$ in airlift bioreactor were conducted and compared together. The best conditions were the aeration rate of 0.4 vvm with $89.28 \%$ of ethanol production yield (Alcohol production was 3 (w/v) percent). It was $90.7 \%$ at the optimal conditions in concentrated whey media with $100 \mathrm{~g} / \mathrm{l}$ lactose.

\section{References}

1. Kosikowski FV (1979) Whey utilization and whey products. J Dairy Sci 62 1149-1160.

2. Dubois M, Gilles KA, Hamilton JK, Rebers PA, Smith F (1956) Colorimetric method for determination of sugars and related substances. Anal Chem 28 350-366.

3. Siso MIG (1996) The biotechnological utilization of cheese whey: a review. Biores Technol 57: 1-11.

4. Gonzalezsiso M (2000) Respirofermentative metabolism in Kluyveromyces lactis: ethanol production and the Crabtree effect. Enzyme Microbiol Technol 26: 585-591.

5. http://www.agri-outlook.org/dataoecd/54/15/40715381.pdf

6. Smithers GW (2008) Whey and whey proteins-from 'gutter-to-gold'. Int Dairy J 18: 695-704.

7. Moulin G, Guillaume M, Galzy P (1980) Alcohol production by yeast in whey ultrafiltrate. Biotechnol Bioeng 22: 1277-1281. 
Citation: Ghanadzadeh H, Ghorbanpour M (2012) Optimization of Ethanol Production from Cheese Whey Fermentation in a Batch-Airlift Bioreactor. J Bioengineer \& Biomedical Sci 2:111. doi:10.4172/2155-9538.1000111

8. Gawel J, Kosikowski FV (1978) Improving alcohol fermentation in concentrated ultrafiltration permeates of cottage cheese whey. J Food Sci 43: 1717-1719.

9. Janssens JH, Bernard A, Bailey RB (1984) Ethanol from whey: Continuous fermentation with cell recycle. Biotechnol Bioeng 26: 1-5.

10. Terrell SL, Bernard A, Bailey RB (1984) Ethanol from Whey: Continuous Fermentation with a Catabolite Repression-Resistant Saccharomyces cerevisiae Mutant. Appl Environ Microbiol 48: 577-580.

11. Ryu YW, Jang HW, Lee HS (1991) Enhancement of ethanol tolerance of lactose assimilating yeast strain by protoplast fusion. J Microbiol Biotechnol 1: 151-156.

12. Ferrari MD, Loperena L, Varela $H$ (1994) Ethanol production from concentrated whey permeate using a fed-batch culture of Kluyveromyces fragilis. Biotechnol Lett 16: 205-210.

13. Domingues L, Lima N, Teixeira JA (2001) Alcohol production from cheese whey permeate using genetically modified flocculent yeast cells. Biotechnol Bioeng 72: $507-514$

14. Silveira WB, Passos FJV, Mantovani HC, Passos FML (2005) Ethanol production from cheese whey permeate by Kluyveromyces marxianus UFV3: a flux analysis of oxido-reductive metabolism as a function of lactose concentration and oxygen levels. Enzyme Microb Technol 36: 930-936.

15. Domingues L, Lima N, Teixeira JA (2001) Alcohol production from cheese whey permeate using genetically modified flocculent yeast cells. Biotechnol Bioeng 72: $507-514$.

16. Box G, Hunter W, Hunter S (1978) Factorial design at two levels. In: Statistics for experimenters, an introduction to design, data analysis and model building. John Wiley and Sons, New York 306-644.

17. Domingues L, Dantas MM, Lima N, Teixeira JA (1999) Continuous ethanol fermentation of lactose by a recombinant flocculating Saccharomyces cerevisiae strain. Biotechnol Bioeng 64: 692-697. 